\title{
Fe-In-S (Iron-Indium-Sulfur)
}

\section{Raghavan}

[88Rag] reviewed the limited structural data on this system. [79Rus] and [81 All] have determined a pseudobinary section along the $\mathrm{FeS}-\mathrm{In}_{2} \mathrm{~S}_{3}$ join.

\section{Update}

In the In-S binary system, $\alpha \operatorname{In}_{2} S_{3}$ (denoted $\beta \operatorname{In}_{2} S_{3}$ in [88Rag]) is a low-temperature ordered superstructure of a spinel subcell, with a bct unit cell. $\beta \operatorname{In}_{2} \mathrm{~S}_{3}$, stable between 414 and $750{ }^{\circ} \mathrm{C}$, has the spinel structure with $a=1.0780 \mathrm{~nm}$ [80Lik]. The lattice parameters of the tetragonal superstruc-

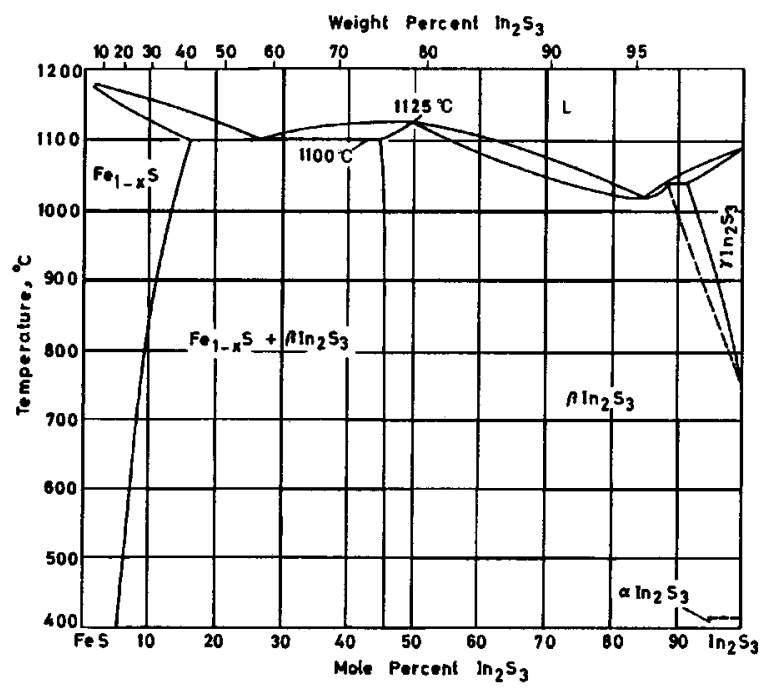

Fig. 1 FeS- $\operatorname{In}_{2} S_{3}$ pseudobinary section [79Rus]. ture are related through $a^{\prime}=a / \sqrt{2}$ and $c=3 a$ [80Lik]. $\gamma \mathrm{In}_{2} \mathrm{~S}_{3}$, stable between $750^{\circ} \mathrm{C}$ and the melting point $1090^{\circ} \mathrm{C}$, has hexagonal symmetry.

[79Rus] and [81All] have determined a pseudobinary section for this system along the FeS- $\mathrm{In}_{2} \mathrm{~S}_{3}$ join. Metallography, $\mathrm{x}$-ray powder diffraction, and DTA measurements were used. This section is redrawn in Fig. 1. FeIn $\mathrm{S}_{4}$ melts congruently at $1125^{\circ} \mathrm{C}$. Up to $55 \mathrm{~mol} \%$ of $\mathrm{FeS}$ dissolves in $\beta \mathrm{In}_{2} \mathrm{~S}_{3}$ and the composition $\mathrm{FeIn}_{2} \mathrm{~S}_{4}$ at $50 \mathrm{~mol} \% \mathrm{FeS}$ is actually a solid solution based on the spinel structure of $\beta \operatorname{In}_{2} S_{3}$ [79Rus, 81 All]. The lattice parameter of $\beta \operatorname{In}_{2} \mathrm{~S}_{3}$ decreases linearly from $\sim 1.070$ $\mathrm{nm}$ at $\mathrm{In}_{2} \mathrm{~S}_{3}$ to $\sim 1.050 \mathrm{~nm}$ at FeIn $\mathrm{S}_{4}$ [79Rus]. Recently, [92Wom] investigated the single-phase spinel region using Mössbauer spectroscopy.

\section{Cited References}

79Rus: P.G.Rustamov, P.K. Babaeva, and M.R. Allazov, "Phase Diagram of FeS-In-In ${ }_{2} S_{3}$ Section,” Zh. Neorg. Khim., 24(8), 2208-2211 (1979) in Russian; TR: Russ. J. Inorganic Chem., 24(8), 1223-1225 (1979). (Experimental;\#)

80Lik: A. Likforman, M. Guittard, A. Tomas, and J. Flahaut, "Evidence for the Solid Solution of the Spinel Type in In-S Phase Diagram," $J$. Solid State Chem., 34, 353-359 (1980) in French. (Experimental;\#)

81All: M.R. Allazov, P.K. Babaeva, A.N. Mamedev, and P.G. Rustamov, "Thermodynamic Analysis of Fusibility Diagrams of GaS-CoS, GaSNiS and $0.5 \mathrm{FeIn}_{2} \mathrm{~S}_{4}$-FeS Systems," Neorg. Mater., 17(2), 349-350 (1981) in Russian. (Review;\#)

88Rag: V. Raghavan,"The Fe-In-S System," Phase Diagrams of Ternary Iron Alloys. Part 2, Indian Institute of Metals, Calcutta, 145 (1988). (Review)

92Wom: M. Womes, J. Olivier-Fourcade, J.C. Jumas, F. Aubertin, and U. Gonser, "Characterization of the Single Phase Region with Spinel Structure in the Ternary System $\mathrm{In}_{2} \mathrm{~S}_{3}-\mathrm{FeS}-\mathrm{FeS}{ }_{2}$," J. Solid State Chem., 97(2), 249-256(1992). (Experimental)

\# Indicates presence of a phase diagram. 